\title{
The historical anthropology of the seventeenth century entrepreneurial activities of the Armenian merchants in New Julfa
}

\author{
Emilia Nercissians (D)
}

Correspondence: enerciss@ut.ac.ir Department of Anthropology, Faculty of Social Sciences, the University of Tehran, Tehran, Iran

\begin{abstract}
This paper reviews the socio-cultural, anthropological reasons for merchant success of Armenian immigrants to New Julfa in the seventeenth century. This includes the importance of entrepreneurial, anthropological studies, and cultural aspects on individual and social levels. The key enabler is the networking and support entities. A case research provides a historical example to analyze their success with theoretical arguments. The importance of new business from social creativity in minorities, combined with risk-taking seems inversely distributed from the diaspora.
\end{abstract}

Keywords: Contemporary applied anthropology, Ethnic entrepreneurship, Entrepreneurial anthropological studies, Migrants and ethnic minorities

\section{Introduction}

Statistics from several European countries indicate that proportionately more migrants and members of ethnic minorities than nations start small businesses (Fairlie, R. W. and et al., 2010; Kerr, S. P. and Kerr, W. R., 2016; Lofstrom, M., 2002).

The extent to which an ethnic group minority business demonstrates distinctive behavioral attitudes and experiences distinctive support needs vary. Research has also drawn attention to the tendency of many ethnic entrepreneurs to focus on ethnic customers and markets (Kerr, W.R. and M. Mandorff, 2015).

Other entrepreneurs may leverage the intrinsic ethnic nature of the product or service offered or relies on informal sales and marketing methods facilitated by their communal organization (Dana, 2007; Saxenian, 2002; Portes and et al., 2002; Schiller and et al., 1992). However, it argued that anthropology could extract information, about cultural issues that lead to entrepreneurial activities and shades light on this type of studies in a broader sense. The literature on entrepreneurship strongly emphasizes the particular psychological traits of the entrepreneurs. These psychological traits are five such as Passion, based on hard work, focused on the dreams and vision, and not gave up when challenged arose; Motivation, dedication to work; Optimism, looking ahead for brighter future; Creativity, different way of thinking and doing; Risk taking, not being scared of taking new measures. These psychological traits mainly refer to the

(c) The Author(s). 2019 Open Access This article is distributed under the terms of the Creative Commons Attribution 4.0 International License (http://creativecommons.org/licenses/by/4.0/), which permits unrestricted use, distribution, and reproduction in any medium, provided you give appropriate credit to the original author(s) and the source, provide a link to the Creative Commons license, and indicate if changes were made. 
strategy of adaptation and integration of the newcomers to the new society that it is very different from their previous one (Altinay, 2008). Social and cultural factors that enter into the formation of entrepreneurial events are manifold. One of the most important aspects is the formation of an individual value system.

Der Hovhanian (Der Hovhanian, 1880) states “... the reason of progress and readiness among the Armenian merchants in their profession was due to two reasons. First, their loyalty, faithfulness, honesty, cleverness, effort, seriousness and accounting skills and second the desire of famous and rich merchants in training the young ones as their successors". Anthropological studies can identify how individuals can have the entrepreneurial spirit and what enculturation processes can promote entrepreneurship. Ethnography and anthropology (Kottack, 2016) center on the concept of culture. They are looking at a series of basic questions such as "What is the nature of culture?" "How does the culture be presented, consolidated, modified, transmitted, or rebuilt?" The aim of this paper is to analyze the socio-cultural situation of the Armenian merchants as immigrants to New Julfa. The entrepreneurial activities of these merchants in quite a different setting considered through anthropological approach because of its comprehensive and holistic viewpoints (Kottack, 2016) to evaluate and examine the mercantile activities of in the context of the whole system under Shah Abbas. Shah Abbas during the Safavid-Ottoman war of 1603-05, and the subsequent forced migration of the native Armenian population, led to the rise of New Julfa, a wealthy mercantile suburb in Isfahan (Hamel, 2017). New Julfa soon became renowned for its silk production. Drawing the attention of Shah Abbas, the Armenians of New Julfa received privileged treatment. It was this privileged treatment that arguably propelled New Julfa to "unparalleled heights of economic prosperity" (Aslanian, 2011).

Herbert Spencer is one of those that refer to an evolutionary (Du Cerceau, 1728) approach in social thought. According to Spencer, it was obvious that all aspects of the world from organic to non-organic, from social to non-social, eventually became subject to evolutionary laws. As a Darwinian, he believed in the evolutionary view that the universe continually grows to a more developed state (Ritzer, 2013). Spencer also states that humans, in contrast to other organisms, instead of biological adaptation, use cultural one for their environmental changes (Rumney, 1966). Socio-cultural adaptation of the Armenian merchants in the new environment took place through their career and expanded network with their fraternities and companions in trade centers of those days.

Entrepreneurs changed the life style of residents in New Julfa. The successful merchants through their innovations improved not only their own life but established a new standard of living, in addition to creating wealth with their entrepreneurial ventures, they also created prestigious jobs for Armenians and consequently prosperous society for other residents of New Julfa. In addition, it is also important to study entrepreneurship not merely as an individual propensity, but also as a social institution (Steyaert and Katz, 2004).

As Schumpeter (2006) pointed out several decades ago (and Adam Smith earlier), the personal profit motive is a central engine that powers private enterprise and social wealth. Entrepreneurship is particularly productive from a social welfare perspective when, in the process of pursuing selfish ends, entrepreneurs also enhance social wealth by creating new markets, new industries, new technology, new institutional forms, new jobs, and net increases in real productivity. 
A different anthropological approach to entrepreneurship, focus on the concept of entrepreneurial culture in the Weberian sense. Rites and processes of transmission of the norms that promote entrepreneurial activity would constitute the main (McDowell, 2014) research area. Interactions between the entrepreneurial subculture and the milieu in which it develops would be a subject area for sociological, socio-psychological, and anthropological analysis. In recent years, glocal issues have become topics of great interest in entrepreneurial research. The concept of Diaspora Entrepreneurial Network recently elaborated drawing upon the conceptualization of Commercial Networks and Trade Diaspora explicated in recent historical research. The author, for example, has investigated how the southern part of the Iranian Armenian community, after the fall of Safavid dynasty and political upheavals caused by the Afghan invasion and intra-dynasty wars, reorganized itself in global scale to continue its entrepreneurial success and compete with Western Colonialism for more than a century.

\section{Method}

Historians seek to develop accurate descriptions of social phenomena on the basis of a careful consideration of all relevant and available data. They strive to understand events in their full context (Elton, 1968). Historical research method by examining the reasons behind the events enables us to take lessons from the past. Historical method defined as "a process of critically examining and analyzing the records and survivals of the past" (Gottschalk, 1969).

According to Golder (2000) "Historical method is the process of collecting, verifying, interpreting, and presenting evidence from the past".

This method by surveying different sources such as public records, archives, library studies, written records from government libraries, courthouses, churches, and private papers tries to synthesize those data and come across new conclusions and unveil or reveal past events. "Historical research is concerned with determining, evaluating, and understanding past events primarily for the purpose of gaining a clear understanding of the present and a better prediction of the future" (Gillmore, 1972). To reach a research question an intensive reading with an analytical mind is the first step. In this step, you are not reading for the sake of reading but reading for formulating an idea through all the existing content of the reading material for answering the question (Grint \& Gardiner, 1954; McDowell, 2014). After turning many primary and secondary sources such as the diaries of travelers (Chardin, 1927; Dubeux, 1881) and historical documents (Du Cerceau, 1728) in different languages, we were provided with vast information and data about the Armenian merchants, their social status under Shah Abbas and also their lifestyle. The study of past, strike us with a question that what was the framework of entrepreneurship among the migrated merchants in Isfahan? In this paper, the lifestyle and social behavior of Armenian migrated merchants is the core subject of investigation. The Armenian merchants' success story of Julfa, a section of Safavid dynasty's capital city of Isfahan, is the subject of this study who lived in Iran since 1602. It is worth mentioning that they were far from their homeland and were active in trade and entrepreneurial ship not only in Iran who resides there but in Europe, Java, India and etc. (Der Hovhanian, 1880). 


\section{Research aim and theoretical framework}

The major question for an anthropological approach to entrepreneurial research is the relationship between the condition of otherness and spirit of entrepreneurship in the wake of rapid social change. Ethnic entrepreneurship is an exemplary case. Theoretical analysis concerning counterculture, deterritorialization, as well as social and cultural capitals, could provide a sound theoretical basis.

Deluze and Guatari (Deluze \& Guattari, 1987), state the concept of a rhizome. They echo, the "... principle of signifying rupture ... a rhizome that may be broken, shattered at a given spot, but it will start up again on one of its old lines, or new lines". They use the example of ants:

"you can never get rid of ant because they form an animal rhizome that can rebound one more time and again after most of it has been destroyed" (ibid). They further claim that the rhizome deterritorializes in one place and reterritorialize in another. The concept of Rhizome is analytical to a tree. In this article, Rhizome is analytical to migrated Armenian merchants, especially when we come across the main characteristic of rhizome, with emphasizing the principle of connection and heterogeneity. Rhizome can be connected to anything other. Basically, the rhizome establishes a connection between everything such as combined rhizome that is themselves made up of the combination of other rhizomes. If we take the concept of rhizome, deterritorialization, and territorialization of Deluze and Guatari's, then we can see how the Armenian merchants functioned as rhizomes, expand their relationships and networks with other merchants (rhizomes) and establish their business in different territories. While the Georgian community who brought to Iran mainly for strengthening the military with reducing the power of Qizilbashes or those days army, and held numerous functions as officials and/or militants were not capable to expand their networks.

The impact of transnational activities of Armenian ethnic group as migrants upon Safavid economy and society was much higher compared with the activities of other ethnic groups with the potential that could contribute to the economic development of Safavid era (Matthe, 1999). Possible causes of this could be included in the specific characteristics of the Armenian Emigrated Merchants and their entrepreneur profile. The fragmentation of transnational networks with other Armenian ethnic groups almost in all over the world and the lack of proper governmental strategies cause them to support and develop their own transnational ethnic entrepreneurial activities that can be understand through what Bourdieu's mentions in the forms of capital.

"Depending on the field in which capital functions, and at the cost of the more or less expensive transformations which are the precondition for its efficacy in the field in question, capital can present itself in three fundamental guises: as economic capital, which is immediately and directly convertible into money and may be institutionalized in the forms of property rights; as cultural capital which is convertible, on certain conditions, into economic capital and may be institutionalized in the forms of educational qualifications; and as social capital, made up of social obligations ('connections'), which is convertible, in certain conditions, into economic capital and may be institutionalized in the forms of a title of nobility" (Bourdieu, 1986). 
Bourdieu \& Passeron (Bourdieu \& Passeron, 1977) are also referring to the concept of cultural capital as the accumulation of knowledge, behavior, and skills that one can tap into to demonstrate one's cultural competence and thus one's social status or standing. According to Bourdieu (1986) cultural capital comes in three forms; embodied, objectify and institutionalized. One's accent or dialect is an example of embodiment, while a luxury car is an example objectification and actual or virtual resources possessed in more or less institutionalized relationship of mutual acquaintance and recognition, forms the third part of cultural capital (ibid).

All three suggested forms of Bourdieu's cultural capital fit perfectly well with the sociocultural and economic situation of Armenian merchants. The ethnicity of Armenian merchants, including the language and culture, were different from the most population of New Julfa. Their huge and luxurious houses (that still one can see the traces of them in New Julfa) were the other evidence of objectification and their institutional network not only with themselves but also with other merchants complete the three forms of cultural capital. Armenian merchants were able not only to reproduce wealth and prestige in the new environment but reproducing unique social strata with their own specifications (Bourdieu, 1974).

Der Hovhanian (Der Hovhanian, 1880) states “... the reason of progress in the trade among the Armenians was due to their readiness for this profession in the first place, their loyalty, faithfulness, honesty, cleverness, effort, seriousness and accounting skills in the second place... The famous and rich merchants were training the young ones as their successors".

Anthropological investigations, from these viewpoints, should concentrate on what can give rise to the innovative spirit and tendency to swim against the flow that would mark the entrepreneurial approach on the individual as well as social levels.

\section{Importance of anthropology in entrepreneurial studies}

The field of entrepreneurship has become an important domain of scientific inquiry due to its growing importance in the contemporary economy. It has drawn upon multiple disciplines, especially business administration and other fields. However, its relationship to social sciences in general, and anthropology in particular, despite widespread recognition of the prominent role of culture in the agenda of entrepreneurial studies, continues to be perceived as secondary. Common themes in the two research traditions also include the accumulation of knowledge and skills, the use of informal networks to acquire access to resources, and opportunity structure, as typically reflected in studies of spatial clustering of entrepreneurship within communities. There have been several pioneering works on entrepreneurship anthropology, and the sub-discipline now enjoys wide recognition. Stewart (Stewart, 1992; Stewart, 2003) for example explores anthropological kinship theory, for potential contributions to a theory of family business. Many topics in kinship-based business, such as the process by which kin become attached to family firms, can only be adequately depicted only with details, longitudinal studies of the type designated as anthropological or ethnographic research. There is also a long tradition of third world studies tracing entrepreneurship to one's connections to the larger community (Kennedy, 1988; Stewart, 1992). Anthropological 
approaches to entrepreneurship are also becoming a focus of attention in Western economies. A topic of rising interest is the prevalence of ethnic domination of certain occupations and businesses in urban areas. One explanation for this could be access to a largely underutilized community resource, maintained not only by the shared traditions held by community members but also their social action.

\section{Ethnic entrepreneurship}

Once a ghetto of underprivileged outsiders and a place to avoid, Chinatowns nowadays stir the imagination of the mainstream population and attract local and international visitors. The business success of ethnic tourist attractions draws our attention to the entrepreneurial side of this development. Ethnic entrepreneurship is set connections and regular patterns of interaction among people sharing a common cultural background or migration experiences. Whereas ethnic ownership economy consists of small and medium-size business owned by ethnic immigrants and entrepreneurs and their co-ethnic helpers and workers, ethnic control economy refers to industries, occupations, and organization of the general labor market in which co-ethnic employees exert appreciable and persistent economic power (Aldrich \& Waldinger, 1990). In recent years, much importance has, been attached to this question. From an economic standpoint, it can be argued that the ability of Western economies to be enterprise-based depends on their ability to encourage and support entrepreneurship in all sections of society, including ethnic minorities. Entrepreneurship in ethnic minority communities can also contribute to reducing social exclusion and raising living standards in groups that can be often among the more disadvantaged in society. Factors influencing the establishment of an ethnic enterprise are multifaceted and include education, generation, the local population, the economic situation, job opportunities, location, cultural and religious differences, and the origin. In her past studies, the author has suggested that the proliferation of ethnic business is an obvious reaction to blocked opportunities in the labor market. Being excluded from mainstream economic activities, and the possibility of leveraging community bonds leads to entrepreneurial social creativity. Because new ethnic populations have grown at a time when Western economies are in a phase of slow growth and massive technological challenge, ethnic adaptation and mobility are central issues to economic research. (Aldrich \& Waldinger, 1990) interactive model combine ethnocultural and socio-cultural factors usually studied under the categorization of an agency. Politico-economic factors, categorized as structure, which entails market condition including access to ethnic and non-ethnic consumer markets as well as access to ownership. In Europe, ethnic minority entrepreneurs have been understood as potential entrepreneurs who are immigrants in the countries concerned. On the one hand, immigrants are more likely to lack human, financial or social resources. On the other, they may experience extra barriers and constraints in the institutional environment, which is the political and economic context of the receiving society. The author has, however, argued that notwithstanding the close relationship between ethnicity and migration, the mutual patterning of identification and massive population movements is much more complex in contemporary postindustrial society. Theorization about ethnic entrepreneurship has led to a convergence of approaches to issues of social embeddedness, that is, the assumption that individual entrepreneurs participate in ethnically specific economic networks that facilitate their business 
operations. In recent years, continental European researchers have argued that these theories of immigrant entrepreneurialism conceptualized the opportunity structure with the assumption of an unregulated and undifferentiated economy. Acknowledging the salience of regulation as well as market dynamics, researchers have proposed a mixed embeddedness approach to immigrant entrepreneurship (Kloosterman \& Rath, 2001). It can be seen that ethnography of entrepreneurship is both an important area of descriptive studies due to its omnipresence in contemporary societies, and at the same time important domain for normative and prescriptive investigations, because of its crucial socio-political importance as for cultural planning efforts towards the goals of participation, empowerment, and inclusiveness (Volery, 2007).

\section{The entrepreneur}

A major starting point for an anthropological analysis of entrepreneurship is the identity of the entrepreneur: it is personality traits, inborn and acquired characteristics, norms and values, and generally conscious and subconscious sets of attitudes, priorities, preferences, and predispositions. Traditional literature on entrepreneurship strongly emphasizes the particular psychological traits of entrepreneurs, such as being innovative and creative, urging for achievement and autonomy, exhibiting risk-taking behavior and individualism. Researchers have developed a multi-dimensional construct of entrepreneurial orientation with three sub-dimensions: innovation, pro-activeness, and risk-taking, and established its validity in several national samples (Kreiser et al., 2002). It should be emphasized that entrepreneurial spirit, by itself, even when coupled with all components of caution so as to sustain a reasonable likelihood of success, need not necessarily be accompanied with higher incomes. Hamilton (2000) finds that in the United States, median entrepreneurs earning after 10 years in business are $35 \%$ less than the predicted alternative wage on a paid job of the same duration. Evidence shows that higher-ability workers are more likely to enter into self-employment. The seeming contradiction could be resolved if one considers other benefits like being one's own boss, which could induce entrepreneurially inclined individuals to forgo income and to bear costs, including through increased risk levels, in order to engage in an independent venture. It should be stressed, however, that the entrepreneurial self is never total given.

In the contemporary postmodern era, the construction of identity, conceptualized as a discursive process that is dependent on time, place and context. Construction of identity also conceived as multiple, and situation dependent: Identity constructed through diverse identity, categories such as gender and ethnicity, which have various power implications; and dialogically constructed elaborating on who they are and want to be, often in pursuit of ideal selves constructed via face management.

The emergence of the entrepreneurial self, therefore, can be investigated only by drawing upon ethnographic field methods and auxiliary tools like sociolinguistics and discourse analysis (Licht \& Siegel, 2006).

\section{Entrepreneurial culture}

In addition to the studies of entrepreneurial orientation for an individual, many researchers have held that high business performance is dependent on the strength of entrepreneurial culture at the organizational level. Little research, however, has 
been conducted to understand the factors and conditions that produce entrepreneurial orientation at the firm level. Within the framework of this descriptive approach to the indices of the entrepreneurial subculture, most researchers do not pay much attention to the rites and processes of transmission of the norms. Norms which provide entrepreneurial activity with a power of primary or secondary socialization; neither does the descriptive approach take into account the diversity of interactions within a single culture and between that culture and the entrepreneurial subculture. Among the refinements in cultural theory that the turn away from structuralism can enable is the recognition that people's sentiments, identities, and social agency are not dictated by culture but are formed through everyday practices that are themselves culturally produced. The functionalist models of institutional domains, on the other hand, too readily grant cultural significance to the observer's analytic categories without adequate ethnographic evidence on how actually to organize their thoughts and actions. All social action is constituted by the multiplicity of discourse and meaning. Consequently, mere explication of these discourse and meanings will not automatically enable us to understand their articulation in the formation of social action. Such an understanding requires knowledge of the ways in which people in specific circumstances connect these discourses and negotiate their complex meanings. The poststructuralist approach, which views the concept of culture as a process rather than a stable structure or system, enables us to transcend the limitation of a passive concept of culture as either a resource to be used in the advancement of capitalist goals or a constraining system that must be broken through if entrepreneurial logic is to be actualized. It can thus be seen that the different approaches in social sciences in general, and anthropology in particular, can inform us not only in the subdomain of ethnic entrepreneurship but also in the analysis of entrepreneurial orientation at both individual and social levels (Basso et al., 2007; Hjorth \& Kostera, 2007; Licht \& Siegel, 2006).

\section{Diaspora entrepreneurial network}

The entrepreneurial culture is not the only thing that serves to show that an anthropological approach is needed not only for a subdomain discussing ethnic entrepreneurship. Both the objective and structural elements and the subjective and agency elements present in the anthropological discussion of ethnicity are also present in the anthropological discussion of culture. Both notions have individual and social dimensions. It is, therefore, possible to conclude that whatever importance could be attached to the study of ethnic entrepreneurship, could also be attached to entrepreneurship in general, insofar as it incorporates the concept of entrepreneurial culture. A similar argument can be made if we compare the notion of ethnicity, not to the notion of culture, but to the community notion. Communities also have both elements: the sense of belonging and the patterning of social interactions that are there in the conceptualization of ethnicity. Baghdiantz and et al. (Baghdiantz et al., 2005) have recently generalized the concepts of trade in diaspora and business network, to theorize about the new concept of diaspora entrepreneurial networks and not simply with merchants but entrepreneurs operating in Eurasian markets and in inland as well as maritime networks. 
The concept refers to entrepreneurs organized in communities that share the same practices and characteristics that can be leveraged to pursue successful business strategies employed over extended times.

From very humble origins, starting as peddlers and hawkers, as well as shopkeepers and merchants, the protagonists described in numerous examples provided by the sited source managed to accumulate resources and to begin their journeys to every bazaar, emporium and entrepot they could, taking advantage of opportunities as well as coordinated use of scarce resources, political changes, crises and fluctuation. Similar notions of transitional and diaspora knowledge networks or transitional entrepreneur communities have been elaborated by other researchers. These refer to specific forms of economic adaptation of foreign minorities in advanced societies, based on the mobilization of their cross-country social networks. A burgeoning literature has explored the cross-national entrepreneurial activities of transnational individuals, including the establishment of remittance handling agencies, import/export firms, cultural enterprises, and manufacturing or service foreign direct investment. Where migrants face formidable obstacles to economic incorporation in their host societies, transnational entrepreneurship can become more attractive and sometimes necessary occupational path. It is increasingly recognized that diaspora knowledge networks may contribute to the benefits of the migration process. In receiving -host- countries by providing valuable international linkages that bring new ideas and skills; in migrant source countries by strengthening ties with their emigrant abroad; and to the migrants themselves, by giving them platform for the exchange of experiences and valuable contacts for their professional and private lives. The importance of local knowledge has been the subject of many entrepreneurial studies (Yanagisako, 2002). Diaspora knowledge networks have deeply changed the way in which highly skilled mobility is looked. They have conceptually subverted the traditional brain drain migration outflow into a brain gain skills circulation by converting the loss of human resources into a remote although accessible asset of expanded networks (Mahroum et al., 2006). The author has argued that local knowledge need not always be at explicit and even conscious levels. It can also be tacit and embedded in community rituals, dominant discourses, and practice (Nercissians \& Fremerey, 2008).

\section{The historical case example and theoretical argument}

As an example of how community networks can be leveraged for successful entrepreneurial activities, one may refer to the Nercissians (Nercissians \& Fremerey, 2008) research on the Iranian-Armenian parish centers in the historical capital of the Safavid dynasty in Isfahan. Initially being forcefully deported from their own lands in 1602 by Shah Abbas, the king of Safavid dynasty, the community entrepreneurs soon recognized themselves as strong trading and entrepreneurial community marketing the goods to many different markets in the remote corners of the world (Chardin, 1927; Der Hovhanian, 1880; Dubeux, 1881; Jackson, 1906; Matthe, 1999). Their success, expressed in contemporary economic theory, guaranteed because they could build up and utilize impressive knowledge capital, social capital, and cultural capital using their community sources. Ghougassian (1998), the author of the history of Nader Shah states "The Armenians, as others were under the pressuer of taxes. They left the country by stating 
numerous excuses such as trade or pilgrimage ... and this was the cause of leaving most of the inhabitants from Julfa".

Some years later in 1694 under Shah Sultan Hossain and Afghan's invasion in 1722, part of the victim community did not survive the horrors of the forced migration. The other part left at the mercy of events under the rule of despotic governors in a strange land whose customs and religious beliefs did not share with the other inhabitants ( $\mathrm{Du}$ Cerceau, 1728). Soon they transferred themselves into a mighty civil society that for centuries could compete with the Western colonizers that despite the support of the political and military might of the strongest imperial governments at the time had to capitulate repeatedly.

Even after the downfall of the Safavid dynasty the Armenian community extended itself to form a close-knit diaspora network, called Iran-o-India parish with including Armenian communities in many countries from the Far East (in Asia) to Europe, and could still challenge the mightiest colonial power for at least another century (Dubeux, 1881). History has all but forgotten the strange fact that a civil society could force imperial governments to negotiate and conclude agreements and treaties that amounted to their capitulation in more than one occasion, by only having the informal community organizational resources to seek support from. But those resources, when used skillfully drawing upon bonds of trust, webs of local and global knowledge, communication and financial systems that were too advanced for their times, and cultural assets within the community, were enough to overcome any sanctions, political and military campaigns, even outright piracies carried out by their mighty antagonists.

\section{Conclusion}

It sought to demonstrate that anthropology constitutes the basis for any scholar analysis of entrepreneurship. The relevance of anthropology is of course very evident for subareas like family entrepreneurship and ethnic entrepreneurship. However, those subareas are exemplary; it has been argued, for all other aspects of entrepreneurial studies as well. Firstly, entrepreneurial studies begin with the conceptualization of the entrepreneur. That is surely an anthropological category. Secondly, the entrepreneurial culture, at the institutional and cultural anthropology in particular. Thirdly, the entrepreneurial organizational context is also subjected to anthropological discussion. More generally, a discussion of the innovative spirit and risk-taking propensity that is so basic in entrepreneurship analysis goes beyond the confine of the business and other disciplines. The entrepreneur most of all should be capable of taking advantage of the opportunities and converting liabilities into assets. The fragmentation of transnational networks with other Armenian ethnic groups almost in all over the world and the lack of proper governmental strategies cause them to support and develop their own transnational ethnic entrepreneurial activities that can be understand through what Bourdieu's mentions in the forms of capital. A socio-culturally informed approach could detect the notion of otherness underlying conditions forcing the entrepreneur to seek a different route. Seeking a different route is a lesson that may be taken from history for the nowadays immigrants in all over the world. Immigration is not a constraint; it may provide innovation and expansion of new horizon and new opportunities.

It is not by coincidence that entrepreneurial spirit is unevenly distributed in reverse relationship between various indices and characteristics correlated with hegemony like 
ethnicity and gender. That is another reason why ethnic entrepreneurship is so exemplary. Not being in the mainstream is an important force for social creativity. Let us conclude by pointing out the notion of deterritorialization as articulated by Deleuze and Guattari (Deluze \& Guattari, 1987). Contemporary critical anthropology celebrates notions of diaspora and hybridity as spaces of subversion. It is the spaces in the margins that vaunted as the location of resistance and intervention in hegemonic narratives of race, culture, and nation. The example of the Iranian Armenian migrant community is most telling. Entrepreneurship studies, on the other hand, with their emphasis on innovation and alterability provide a postmodern context for anthropology whose preoccupation has been to study otherness. Can we claim that the main agenda for anthropology has always been that and to seek the entrepreneurial orientation?

\section{Acknowledgments}

The author is grateful for the contribution of the Journal of Global Entrepreneurship Research for its supporting policies for researchers. The author would like to thank Dr. Arman Lucas for providing the initial idea of this paper and also Mr. Pederm Keyhani and Frederick Carapetian for their sincere help with the typing and arranging technical issues of this paper.

\section{Funding}

The author declares that she has received no funding from any source.

\section{Availability of data and materials}

Further information and questions can be provided and answered upon request. The author permits unrestricted use, distribution, and reproduction in any medium only by mentioning the original author and the source.

\section{Author's contribution}

The article wrote by the author and she approves the final manuscript.

\section{Competing interest}

The author declares that she has no competing interest and approves the manuscript for submission for the first time in this journal and has never submitted for publication elsewhere.

\section{Publisher's Note}

Springer Nature remains neutral with regard to jurisdictional claims in published maps and institutional affiliations.

Received: 26 February 2018 Accepted: 4 December 2018

Published online: 08 February 2019

\section{References}

Aldrich, H., \& Waldinger, R. (1990). Ethnic entrepreneurs: Immigrant business in industrial societies. Contemporary Sociology, 69(3), 111-135. https://doi.org/10.2307/2072935.

Altinay, L. (2008). The relationship between an Entrepreneur's culture and the entrepreneurial behaviour of the firm. Journal Small Business and Enterprise Development, 1(15), 111-129.

Aslanian, S. D. (2011). From Trade Diasporas to Circulation Societies. In From the Indian Ocean to the Mediterranean (pp. 122). University of California Press. https://doi.org/10.1525/california/9780520266872.003.0001.

Baghdiantz, I. M., Harlaftis, G., \& Minoglou, I. P. (2005). Diaspora entrepreneurial networks: Four centuries of history. Oxford: Burg. https://doi.org/10.1017/s174002280621307X.

Basso, O., Bouchard, V., Fayolle, A., \& Legrain, T. (2007). Understanding the Impact of Culture on a Firm's Entrepreneurial Orientation and Behavior: A Conceptual Framework. Working Paper\#2008-02 Conference RENT XXI: Rresearch in Entrepreneurship and Small Business. Cardiff: Fayolle Alain. Retrieved from https://www.researchgate.net/profile/Fayolle_ Alain/publication/255587341_Understanding_the_Impact_of_Culture_on_a_Firm's_Entrepreneurial_Orientation_and_ Behavior_a_Conceptual_Framework1/links/556c04d808aeccd7773a21fd.pdf

Bourdieu, P. (1974). Cultural Reproduction and Social Reproduction. London: Tavisstock. https://books.google.com/books?hl= en\&lr=\&id=79DGnwT_vfUC\&oi=fnd\&pg=PA173\&dq=Cultural+Reproduction+and+social+Reproduction.+London:+ Tavisstock\&ots=Lzn8jLyZnU\&sig=ECBFzxFv1 bQ-LimG-q|50069ZOC\#v=onepage\&q\&f=false.

Bourdieu, P. (1986). The forms of capital. In: Richardson, J., Handbook of Theory and Research for the Sociology of Education Westport, CT: Greenwood: 241-58. http://www.socialcapitalgateway.org/content/paper/bourdieu-p-1986-forms-capitalrichardson-j-handbook-theory-and-research-sociology-educ.

Bourdieu, P., \& Passeron, J. (1977). The Forms of Capital. Handbook of Theory of Research for the Sociology of Education. Westport, CT: Greenwood. Retrieved from http://home.iitk.ac.in/ amman/soc748/bourdieu forms of capital.pdf

Chardin, J. (1927). Travels in Persia 1673-1677. London: Argonant. Retrieved from https://books.google.com/books/about/ Travels_in_Persia_1673_1677.html?id=5jPLOA31H5MC

Dana, L. (2007). Handbook of Research on Ethnic Minority Entrepreneurship. 
Deluze, G., \& Guattari, F. (1987). A Thousand Plateaus: Capitalism and Schizophrenia. Minnesota: University of Minesota. Retrieved from http://composingdigitalmedia.org/digitaliteracy/docs/Deleuze_guat_Rhizome.PDF

Der Hovhanian, H. (1880). The History of Julfa Isfahan. Julfa: Vankee Debaran. ISBN 964-6941-06-0.

Du Cerceau, A. (1728). L'histoire de la dernière revolution de Perse (Vol. 2). Paris: Briasson.

Dubeux, L. (1881). Historia De la Persia. Charleston: Nabu. Retrieved from https://books.google.com/books?id= ICKjLULSOsYC\&printsec=frontcover\&dq=Historia+De+la+Persia\&hl=en\&sa=X\&ved= 0ahUKEwi6qKGLg4DbAhVM6aQKHfJXAJMQ6AEIKTAA\#v=onepage\&q=Historia\%20De\%20la\%20Persia\&f=false

Elton, G. R. (1968). The Practice of History. The American Historical Review. New York: Thomas Y. Crowell Company.

Fairlie, R. W., Zissimopoulos, J., \& Krashinsky, H. (2010). The International Asian Business Success Story? A Comparison ofChinese, Indian and Other Asian Businesses in the United States, Canada and United Kingdom. https://urldefense. proofpoint.com/v2/url?u=http-3A_www.nber.org_chapters_c8221.pdf\&d=DwIGaQ\&c=vh6FgFnduejNhPPD0fl_ yRaSfZy8CWbWnlf4XJhSqx8\&r=2OQQIE35f-LzENF_xG9j-xL3eaChYM_HRUNFHBOLBLI\&m= 6YT8PZ8tSezRYI29A7oLVKQ9sRUDQBXHEhbQOTwLc\&s=yu14RLMYLzpirQSyHmXeBzTqYOgeNXJM8FGtIpSCJ5Y\&e=

Ghougassian, V. S. (1998). The emergence of the Armenian Diocese of New Julfa in the seventeenth century. Atlanta. In Ga: Scholars Press.

Gillmore, G. M. (1972). Book Reviews : Irvin J. Lehmann and William A. Mehrens (Eds.). Educational Research: Readings in Focus. New York: Holt, Rinehart, and Winston, 1971 Pp. xiii $+460 . \$ 6.95$ paperback. Educational and Psychological Measurement, 32(1), 216-219. https://doi.org/10.1177/001316447203200137.

Golder, P. N. (2000). Historical Method in Marketing Research with New Evidence on Long-Term Market Share Stability. Journal of Marketing Research, 37(2), 156-172. https://doi.org/10.1509/jmkr.37.2.156.18732.

Gottschalk, L. (1969). Understanding history: A primer of historical method. New York: Knopf. Retrieved from https:// urldefense.proofpoint.com/v2/url?u=https-3A_trove.nla.gov.au_work_14999306\&d=DwlGaQ\&c=vh6FgFnduejNhPPD0fl_ yRaSfZy8CWbWnIf4XJhSqx8\&r=20QQIE35f-LzENF_xG9j-xL3eaChYM_HRUNFHBOLBLI\&m=6YT8PZ8tSezRYI29A7OLVKQ9-sRUDQBXHEhbQOTwLc\&s=SGD8YBESVrYZILNJqpPot50zqPP7_jxkgxVm9hS_U1c\&e=

Grint, L. A., \& Gardiner, P. (1954). The Nature of Historical Explanation. The Philosophical Quarterly, 4(17), 381. https://doi.org/10. $2307 / 2217386$.

Hamel, C. J. (2017). Safavid Trade During the 17th Century: Iran's Transit Economy. Middle Eastern Communities and Migrations, Student Research Paper Series. 6. James Madison University.https://urldefense.proofpoint.com/v2/url?u=https3A_commons.lib.jmu.edu_mecmsrps_6_\&d=DwIGaQ\&c=vh6FgFnduejNhPPD0fl_yRaSfZy8CWbWnlf4XJhSqx8\&r= 2OQQIE35f-LzENF_xG9j-xL3eaChYM_HRUNFHBOLBLI\&m=6YT8PZ8tSezRYI29A7oLVKQ9\%2D\%2DsRUDQBXHEhbQOTwLC\&s= OGI5iH5qFo4fnOH5t-IWz-FI2P_yUthRmueXEh2HRg8\&e=

Hamilton, B. (2000). Does entrepreneurship pay? An empirical analysis of the return of self-employment. Journal of Political Economy, 108(3), 189-202 Retrieved from https://www.journals.uchicago.edu/doi/abs/10.1086/262131.

Hjorth, D., \& Kostera, M. (2007). Entrepreneurship and the Experience Economy. (D. Hjorth, \& M. Kostera, Eds.) Copenhagen: Copenhagen Business School Press. Retrieved from https://books.google.com/books?id=ngpxg9nYpEAC\&printsec= frontcover\&source=gbs_ge_summary_r\&cad=0\#v=onepage\&q\&f=false

Jackson, A. (1906). Persia Past and Present. In New York: New York, The Macmillan Company. London: Macmillan \& Co., Itd. Retrieved from https://archive.org/details/persiapastpresen00jackrich.

Kennedy, P. (1988). African capitalism: The struggle for ascendency. Cambridge: Cambridge University Press.

Kerr, S. P., \& Kerr, W. R. (2016). Immigrant entrepreneurship(No. w22385). In National Bureau of Economic Research.

Kerr, W., \& Mandorff, M. (2015). Social Networks. Ethnicity, and Entrepreneurship. https://doi.org/10.3386/w21597.

Kloosterman, R., \& Rath, J. (2001). Immigrant entrepreneurs in advanced economies. Mixed embeddedness further explored. (R. Kloosterman, \& J. Rath, Eds.) Journal of Ethnic and Migration Studies. Special Issue on "Immigration Entrepreneurship", 27(2), 189-202. Retrieved from http://janrath.com/downloads/@introduction\%20special\%20issue\%20JEMS\%202001.pdf

Kottack, C. (2016). Mirror for Humanity: A Concise Introduction to Cultural Anthropology / Edition 9. New York: McGraw -Hill Higher Education Publication. p. 11. Retrieved from https://urldefense.proofpoint.com/v2/url?u=https-3A_www. barnesandnoble.com_w_mirror-2Dfor-2Dhumanity-2Dconrad-2Dkottak_1117354856\&d=DwIGaQ\&c= vh6FgFnduejNhPPD0fl_yRaSfZy8CWbWnlf4XJhSqx8\&r=2OQQIE35f-LzENF_xG9jxL3eaChYM_HRUNFHBOLBLI\&m= 6YT8PZ8tSezRYI29A7oLVKQ9--sRUDQBXHEhbQOTwLC\&s=gLFUwxQZLvp14Ph4RjGDOEZDJb08VAHSgnIWB5kTCkw\&e=

Kreiser, P., Marino, L., \& Weaver, K. M. (2002). Assessing the relationship between entrepreneurial orientation, the external environment and firm performance. Frontiers of Entrepreneurship Research, 22(1). Retrieved from https://scholar.google.com/citations?user= o7CIVOMAAAAJ\&hl=en\#d=gs_md_cita-d\&p=\&u=\%2Fcitations\%3Fview_op\%3Dview_citation\%26hl\%3Den\%26user\%3Do7CIV OMAAAAJ26citation for view\%3Do7CIVOMAAAAJ3A4TOpqqG69KYC\%26tzom\%3D-270

Licht, A., \& Siegel, J. I. (2006). The social Dimension of Entrepreneurship. Oxford: OXFORD HANDBOOK OF ENTREPRENEURSHIP, Mark Casson and Bernard Yeung, eds., Oxford University Press. Retrieved from https://ssrn.com/abstract=824844

Lofstrom, M. (2002). Labor market assimilation and the self-employment decision of immigrant entrepreneurs. Journalof Population Economics, 15(1), 83-114. https://doi.org/10.1007/pl00003841.

Mahroum, S., Eldridge, C., \& Daar, A. S. (2006). Transnational knowledge through diaspora networks. International Journal on Multicultural Societies, 8(1), 25-42 Retrieved from http://unesdoc.unesco.org/images/0014/001490/149086e.pdf

Matthe, R. (1999). The Pliitics of trade in Safavid Iran. Cambridge: Cambridge University. Retrieved from https://books.google. $\mathrm{com} /$ books?id=5U0yECMV\%2D\%2DwC\&printsec=frontcover\&source=gbs_ge_summary_r\&cad=0\#v=onepage\&q\&f=false

McDowell, W. H. (2014). Historical research: A guide. London: Routledge.

Nercissians, E., \& Fremerey, M. (2008). Vernacular languages and cultures in rural development: Theoretical discourse and some examples. Journal of Agriculture and Rural Development in the Tropics and Subtropics, 109(1), 65-85 Retrieved from https://jarts.info/index.php/jarts/article/view/74.

Portes, A., Guarnizo, L. E., \& Haller, W. J. (2002). Transnational Entrepreneurs: An Alternative Form of Immigrant Economic Adaptation. American Sociological Review, 67(2), 278. https://doi.org/10.2307/3088896.

Ritzer, G. (2013). Introduction to sociology. Thousand Oaks, Calif: SAGE Publications. https://urldefense.proofpoint.com/v2/ url?u=https-3A_www.worldcat.org_title_introduction-2Dto-2Dsociology_oclc_795464339\&d=DwlGaQ\&c= vh6FgFnduejNhPPD0fl_yRaSfZy8CWbWnIf4XJhSqx8\&\&r=20QQIE35f-LzENF_xG9j-xL3eaChYM_HRUNFHBOLBLI\&m= 6YT8PZ8tSezRYI29A7oLVKQ9--sRUDQBXHEhbQOTwLc\&s=wqluaS7JWBkHC2T35QebtDszqqJs4mFLDIJQMlw6HwE\&e= 
Rumney, J. (1966). Herbert Spencer's sociology: A study in the history of social theory. New York: Atherton.

Saxenian, A. (2002). Silicon Valley's New Immigrant High-Growth Entrepreneurs. Economic Development Quarterly, 16(1), 20-31. https://doi.org/10.1177/0891242402016001003.

SCHILLER, N. G., BASCH, L., \& BLANC-SZANTON, C. (1992). Transnationalism: A New Analytic Framework for Understanding Migration. Annals of the New York Academy of Sciences, 645(1 Towards a Tra), 1-24. doi:https://doi.org/10.1111/j.17496632.1992.tb33484.x

Schumpeter, J. (2006). Capitalism. Socialism and Democracy.

Stewart, A. (1992). A prospectus on the anthropology of entrepreneurship. Entrepreneurship Theory and Practice, 16(2), 71-91. https://doi.org/10.1177/104225879201600206.

Stewart, A. (2003). Help one another, use one another: Toward an anthropology of family business. Entrepreneurship Theory and Practice, 27(4), 383-396. https://doi.org/10.1111/1540-8520.00016.

Steyaert, C., \& Katz, J. (2004). Reclaiming the space of entrepreneurship in society: geographical, discursive and social dimensions. Entrepreneurship \& Regional Development, 16(3), 179-196. https://doi.org/10.1080/0898562042000197135.

Volery, T. (2007). Ethnic Entrepreneurship: A Theoretical Framework. In L. P. Dana (Ed.), Handbook of Research on Ethnic Minority Entrepreneurship: a Co-evolutionary View on Resource Management (pp. 30-41). Cheltenham: Edward Elgar Retrieved from https://www.alexandria.unisg.ch/publications/39658.

Yanagisako, S. (2002). Producing culture and capital family firms in Italy. Journal of Anthropological Research, 60(4), 586-587. https://doi.org/10.1086/jar.60.4.3631154

Submit your manuscript to a SpringerOpen ${ }^{0}$ journal and benefit from:

- Convenient online submission

- Rigorous peer review

Open access: articles freely available online

High visibility within the field

- Retaining the copyright to your article

Submit your next manuscript at $>$ springeropen.com 